(C) Elsevier/INRA

\title{
Use of soft X-radiography for early non-destructive detection of floral differentiation in Douglas fir buds (Pseudotsuga menziesii (Mirb) Franco)
}

\author{
M Bonhomme 1, P Doumas 2, M Bonnet-Masimbert 2, R Rageau ${ }^{1}$ \\ 1 INRA-Université Blaise-Pascal, Unité Associée Physiologie Intégrée de l'Arbre Fruitier (PIAF), \\ Domaine de Crouelle, F63039 Clermont-Ferrand CEDEX 2; \\ 2 INRA, Station d'Amélioration des Arbres Forestiers, F45160 Olivet ,France
}

(Received 22 March 1993; accepted 9 September 1993)

\begin{abstract}
Summary - Weekly X-radiographs were made of Douglas fir buds on growing shoots as a nondestructive method of detecting the onset of their meristem transition from a vegetative to a floral state. The same procedure was followed with sampled shoots to improve the interpretation of previous radiographs made of whole branches on the tree. There was clear evidence of the floral state about 60 $\mathrm{d}$ after the beginning of the flower-promoting treatment. Male and female cones were plainly distinguishable $75--80 \mathrm{~d}$ after the treatment. With this technique, it is possible to non-destructively follow the growth of floral primordia inside the buds. The technique can also be used to characterize bud samples on the basis of more accurate criteria than those of external morphology. Good results were obtained on freeze-dried buds, particularly for showing vascularization at the bud base.
\end{abstract}

\section{Pseudotsuga menziesii / X-radiography / floral bud / floral initiation}

Résumé - Utilisation de la radiographie aux rayons $X$ pour une détection précoce de la différenciation florale des bourgeons du sapin de Douglas (Pseudotsuga menziesii (Mirb) Franco). Sur de jeunes plants de sapin de Douglas nous avons réalisé chaque semaine au cours du mois d'août 1991 une série de radiographies $R X$ sur les bourgeons des pousses en croissance afin de mettre en évidence précocement, mais de façon non destructive, le passage de l'état végétatif à l'état floral. Les mêmes observations ont été faites en parallèle sur des pousses prélevées, pour affiner les interprétations des clichés réalisés sur rameaux en place sur l'arbre. Le passage à l'état floral a pu être détecté de façon certaine environ $60 \mathrm{j}$ après le début d'application du traitement florifère. La distinction entre ébauches florales mâles et femelles ne fait plus de doute $80 j$ après cette même date. Cette technique permet donc de suivre de façon non destructive la croissance des ébauches à l'intérieur des bourgeons. Elle peut également être utilisée pour caractériser des lots de bourgeons sur des critères plus discriminants que ceux basés sur la seule morphologie externe. La technique est utilisable sur des rameaux lyophilisés chez lesquels elle permet, notamment, de mettre en évidence la vascularisation à la base des bourgeons.

Pseudotsuga menziesii / radiographie RX / bourgeon floral / initiation florale 


\section{INTRODUCTION}

The effectiveness of $X$-radiography to determine seed quality has been confirmed by its extensive use over a number of years (Simak and Gustafsson, 1953; Simak and Sahlen, 1981; Chavagnat, 1984, 1985). Radiographs provide morphological information about organs or tissues which would otherwise be masked by others, while preserving plant specimens intact. With this technique, it is possible: (i) to obtain precise information on the morphogenetic development of the plant of particular interest for ontogenetic studies; and (ii) to have a more accurate definition of the state or the development stage of organs and tissues for sampling, especially for sparse material.

Studies on conifer bud initiation/differentiation and development provide excellent examples of the potential use of this technology. Reproductive events take place in axillary buds during the course of the vegetative development of the elongating shoot. The only way to confirm the presence of sexual buds is to use destructive methods such as histology or to wait until bud development is complete, when it is possible to differentiate morphologically male, female and vegetative buds.

Floral ontogenesis in cone buds and the features and conditions by which it is determined are important in forest tree breeding, in which research has been confined to the use of destructive methods. Thus, we tried to detect the transition from vegetative to floral state non-destructively using the radiography of buds. The present work is to our knowledge the first to use $X$-radiography to study, in situ, floral initiation on Douglas fir buds.

\section{MATERIALS AND METHODS}

To increase the likelihood of obtaining enhanced cone-bud production, potted 5 -year-old grafts of
Douglas fir (Pseudotsuga menziesii) were submitted to different flower-inducing treatments (Bonnet-Masimbert, 1987, 1989) at time of bud burst in 1991. Trees 1,2, and 3 received bark girdle and root-flooding treatments. Girdles were double, overlapping, half circumferential bands ( $5 \mathrm{~mm}$ wide). Root flooding was alternated ( $2.5 \mathrm{~d}$ in water with $2.5 \mathrm{~d}$ out of water over $15 \mathrm{~d}$ ). Trees 4 and 5 were treated with hormonal injection and bark girdles. Gibberellin $4 / 7(20 \mathrm{mg})$ and naphthalene acetic acid $(2 \mathrm{mg})$, in $100 \mu$ methanol were injected directly into the trunk ( $5 \mathrm{~mm}$ depth).

For each tree, several shoots located on the 1990 whorls were selected for X-radiography in situ. During the shoot-growth period, we made weekly radiographs of these shoots: for convenience, the potted plants and generator were moved near an electric power supply. Radiographs were made in accordance with safety regulations.

Young shoots with morphologic characteristics similar to those of previous shoots (vigour, presence and distribution of young buds) were also selected for the collection of bud samples throughout the period of experimentation. Samples (3 shoots per tree giving $20-40$ buds) were collected about once every 2 weeks (July 22 for tree number 1 , July 31 for trees $1-5$, August 13 for trees $1-5$, August 22 for trees 1-3, August 26 for trees 4 and 5 , and September 2 for trees 1-5). At each sampling date, the shoots were $\mathrm{X}$-rayed in a shielded chamber after removal of the needles and then immediately put in liquid nitrogen and freeze-dried. After freeze-drying, new radiographs were made. During exposure, shoots were taped on the film (taking care that there was no interference between adhesives and bud pictures) to reduce geometric fuzziness as much as possible.

Radiography was performed with an Andrex $160 \mathrm{kV}$ generator with a beryllium window producing soft $X$-rays $(15 \mathrm{kV})$; the intensity was set at $3 \mathrm{~mA}$ and focus distance at $1 \mathrm{~m}$. Exposure time was about $5 \mathrm{~min}$. Films (double-coated and 'medium' relative speed Kodak Industrex $M$ in 'Ready Pack') were developed in manual Kodak Industrex developer for $5 \mathrm{~min}$ at $20^{\circ} \mathrm{C}$, fixed for 5-6 min in Kodak fixer $\left(20^{\circ} \mathrm{C}\right)$ and thoroughly rinsed in running water.

Histologic sections of buds sampled at the last date of observation were made with a cryomicrotome and stained with carmine-green solution (Johansen, 1940) to compare bud anatomy with the findings from the radiographs, in particular, of freeze-dried buds. 

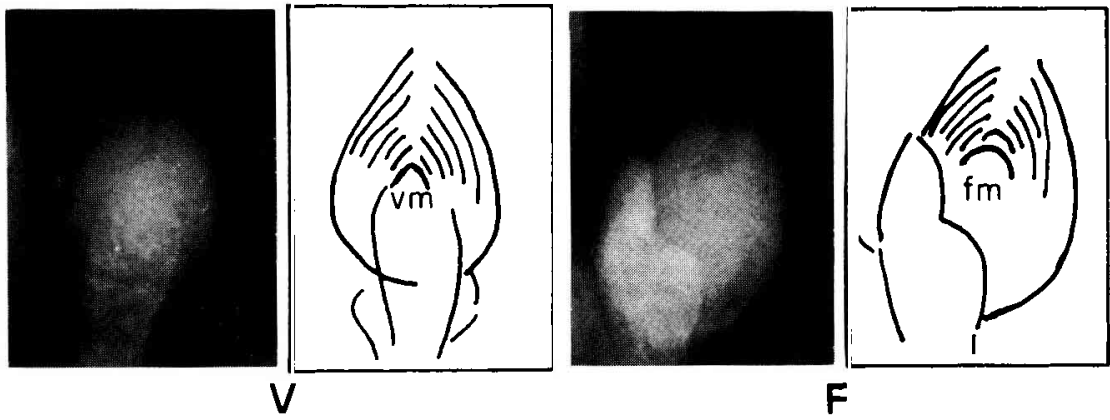

$\mathbf{F}$

Fig 1. Radiographs and interpretative diagrams of vegetative $(V)$ and floral $(F)$ buds on July 31 . The increased size of the meristematic dome on the right-hand picture characterizes the floral state $(\mathrm{fm})$ of the meristem compared with the vegetative state $(\mathrm{vm})$. Enlargement: $x 6$.

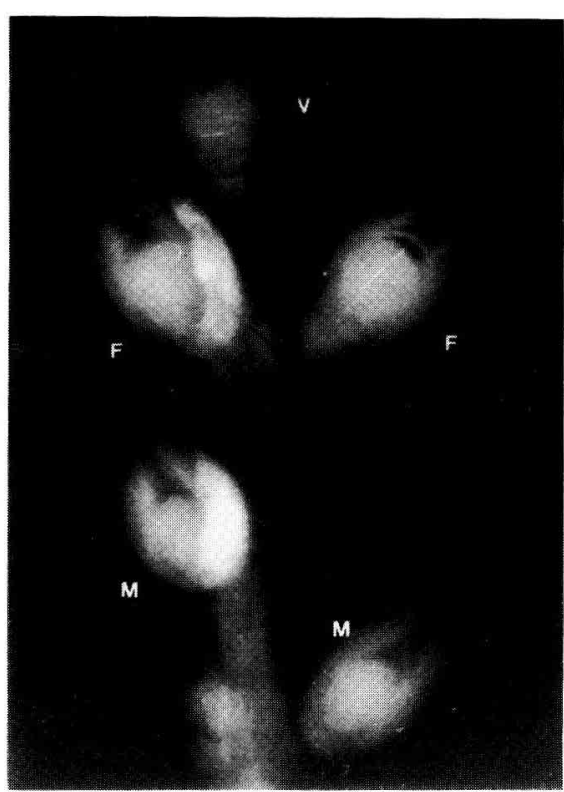

a

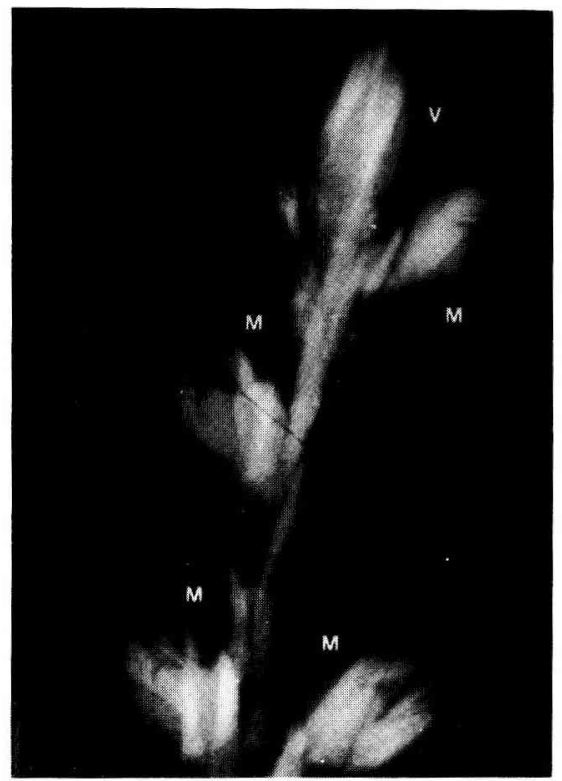

b

Fig 2. Radiographs of shoots on August 22: a) Cut shoot from which needles were removed. Note the flatness of meristematic dome in female bud $(F)$ compared with male $(M)$ or vegetative ( $V$ ) buds; $b$ ) shoot in situ on tree in which pictures of needles and buds are superimposed. Enlargement : $x 4$. 

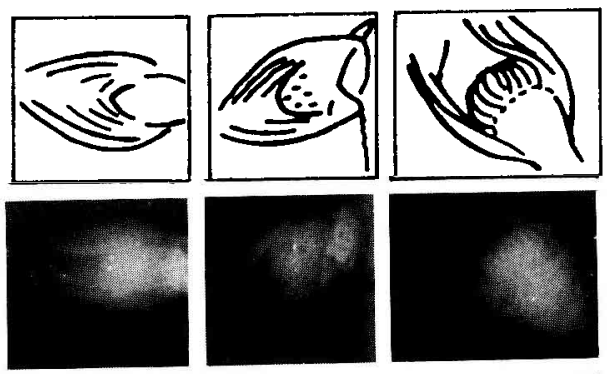

$\sigma$
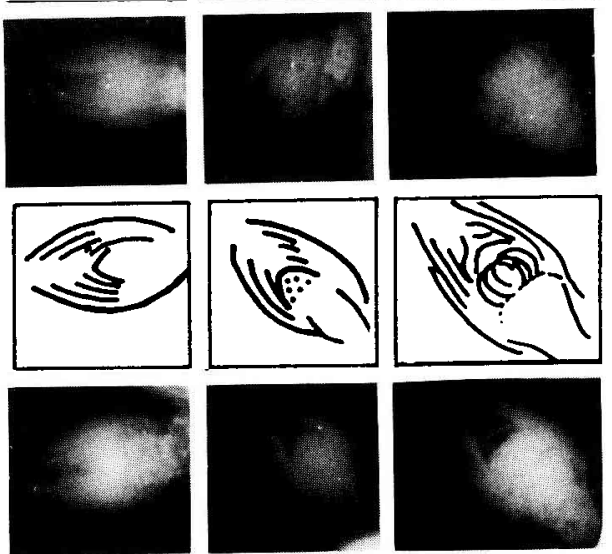

in
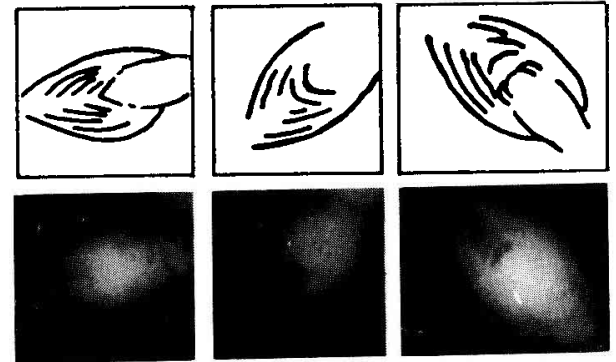

N
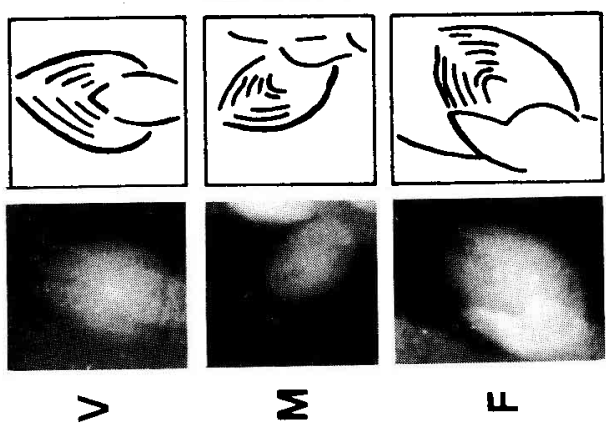

$u$

ธิเ เก

$\Sigma \times$

늠

E

뜬 믄

$\frac{6}{5}$

ن

응 힝

등

¿ळ

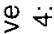

華

茨

$\stackrel{0}{\geq}$

电文

的

눙

들 홀

흥 옹

di

뭉

을

的高

ह

훙

믕

¿

홍

D

흔 웜

.

응

कั

흉항

के

옹

응

용

등 읃

을음

홍

등 ह

훙 음

음

$\llbracket$

लं

욘 을 


\section{RESULTS}

\section{Radiographs of cut shoots}

Sixty-five days after floral treatment (August 13) or fifty-five days after treatment (July 31) for tree 1 with the earlier development, the radiographs generally showed a marked increase in the size of the apparent meristematic dome which expressed the floral transformation (fig 1). At this stage, it was not yet possible to distinguish between male and female parts. However, because of the position of the buds on the shoot, tentative conclusions could be drawn concerning the nature of the flowers. As expected, radiographs of buds made on cut shoots (fig 2a) had a sharper definition than those made in situ on trees (fig 2b).

In the samples of August 22 (80-85 d after treatment), the space between the bud scales near the apparent meristematic dome was greater than in those taken August 13 (65 d after treatment) and the vegetative or floral state of the buds was clearly apparent (fig 3 ). In addition, it was possible to characterize the female buds by the flatness of their apparent apical dome (meristem and bracts of floral part). The images in figure 3 can be usefully compared with those of dissected buds in figure 4. Because of their size and their position on the shoot, only a percentage of buds present could be observed and interpreted on a single radiograph. Table I shows that this percentage depends on the state of bud development on the tree and the date of shoot sampling.

\section{Radiographs of shoots on trees}

The pictures of buds taken in situ (fig 5) were more difficult to interpret than those from the excised shoots because of the difficulty of laying the buds correctly onto the film during exposure, which created greater fuzziness, and also because the pictures of the buds and needles were superimposed.

A lower proportion of in situ buds than buds that had been excised and X-rayed, were thus able to be analysed. On a given date, this percentage depended on the ear-
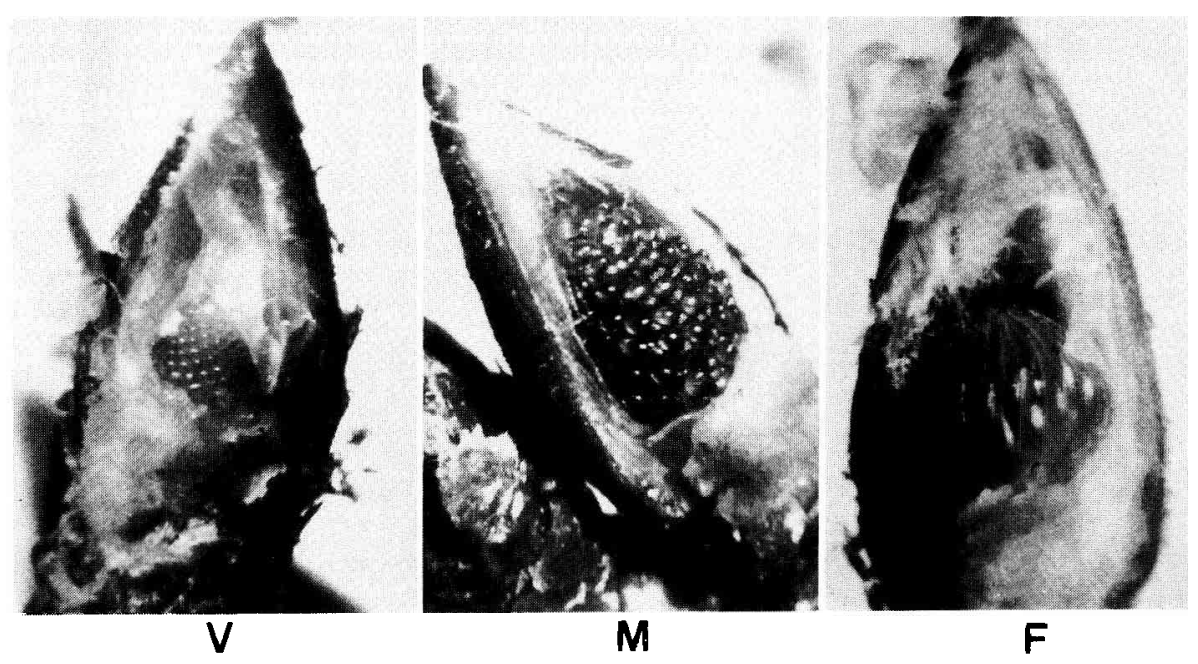

Fig 4. View of dissected buds showing meristematic structure: vegetative bud ( $V$ ), mate bud $(M)$ and female bud $(F)$ in September. Enlargement: $\times 9$. 
liness of the tree phenology and the position of the buds on the shoot. The percentage of the buds that could be analysed increased overall with time as did the size of the buds, from a small percentage on August $5(2-30)$ to almost the total number of buds on September 3 (table II).

The date of floral transformation of some of the buds in these radiographs was estimated as being the same as on the excised shoots. For the population of buds present on selected shoots on the tree, an overall interpretation was made from data collected on August 12 (trees 1, 4, 5) or August 20 (trees 2, 3).

Table I. Percentage of buds that could be clearly interpreted as vegetative, female or male on radiographs of cut shoots, for each tree at each date of sampling

$\begin{array}{cccccc}\text { Date } & \text { Tree } & \text { Tree } & \text { Tree } & \text { Tree } & \text { Tree } \\ & 1 & 2 & 3 & 4 & 5 \\ & & & & & \\ 22 / 07 & 63 & & & & \\ 31 / 07 & 82 & 80 & 96 & 55 & 36 \\ 13 / 08 & 89 & 78 & 76 & 48 & 71 \\ 22 / 08 & 89 & 94 & 86 & & \\ 26 / 08 & & & & 81 & 95 \\ 02 / 09 & 91 & 100 & 100 & 100 & 95\end{array}$

Table II. Percentage of buds that could be clearly interpreted as vegetative, female or male on radiographs of attached shoots in situ, for each tree at each date.

$\begin{array}{cccccc}\text { Date } & \text { Tree } & \text { Tree } & \text { Tree } & \text { Tree } & \text { Tree } \\ & 1 & 2 & 3 & 4 & 5 \\ & & & & & \\ 05 / 08 & 30 & 09 & 02 & 23 & 04 \\ 12 / 08 & 53 & 19 & 13 & 65 & 49 \\ 20 / 08 & 78 & 42 & 45 & 79 & 61 \\ 27 / 08 & 71 & 64 & 84 & 100 & 94 \\ 03 / 09 & 78 & 68 & 90 & 100 & 93\end{array}$

\section{Radiographs of freeze-dried buds}

The radiographs of buds made after shoots had been freeze-dried had much detail (fig 6 ). However, we could only distinguish between the different kind of buds $10 \mathrm{~d}$ later than those from radiographs made of 'fresh' buds. This was probably due to a retraction of the structures during freeze-drying, which induced a reduction in the overall size of the floral parts. The proportional size of the structures was however unchanged.

Radiographs of lyophilised material showed vascularization at the base of the bud. Parallel observations of histologic sections of homologous buds (fig 7) showed that there was xylem vascularization in the shoot and procambium with proto-xylem at the base of the buds. In Douglas fir buds, we observed the presence of a transition zone with enlarged parenchymatous cells corresponding to the crown region described by Allen and Owens (1972), delimiting a 'chamber' at the base of the buds, which quickly changed in shape and size under floral buds. Whether the floral bud was male or female, the structure of the chamber was the same but its development seemed slower under male buds. This difference could be an additional criterion in the interpretation of radiographs made at a very early stage.

\section{DISCUSSION AND CONCLUSION}

X-radiography is commonly used to determine the quality of different seed samples (Chavagnat, 1984) and its non-destructive nature has been widely confirmed. This characteristic is of great interest in experiments in which growth phenomena are studied because it allows the repeated observation of a specific organ, thus avoiding the difficulties of sampling homogeneity. Although we did not check it on the buds, it 

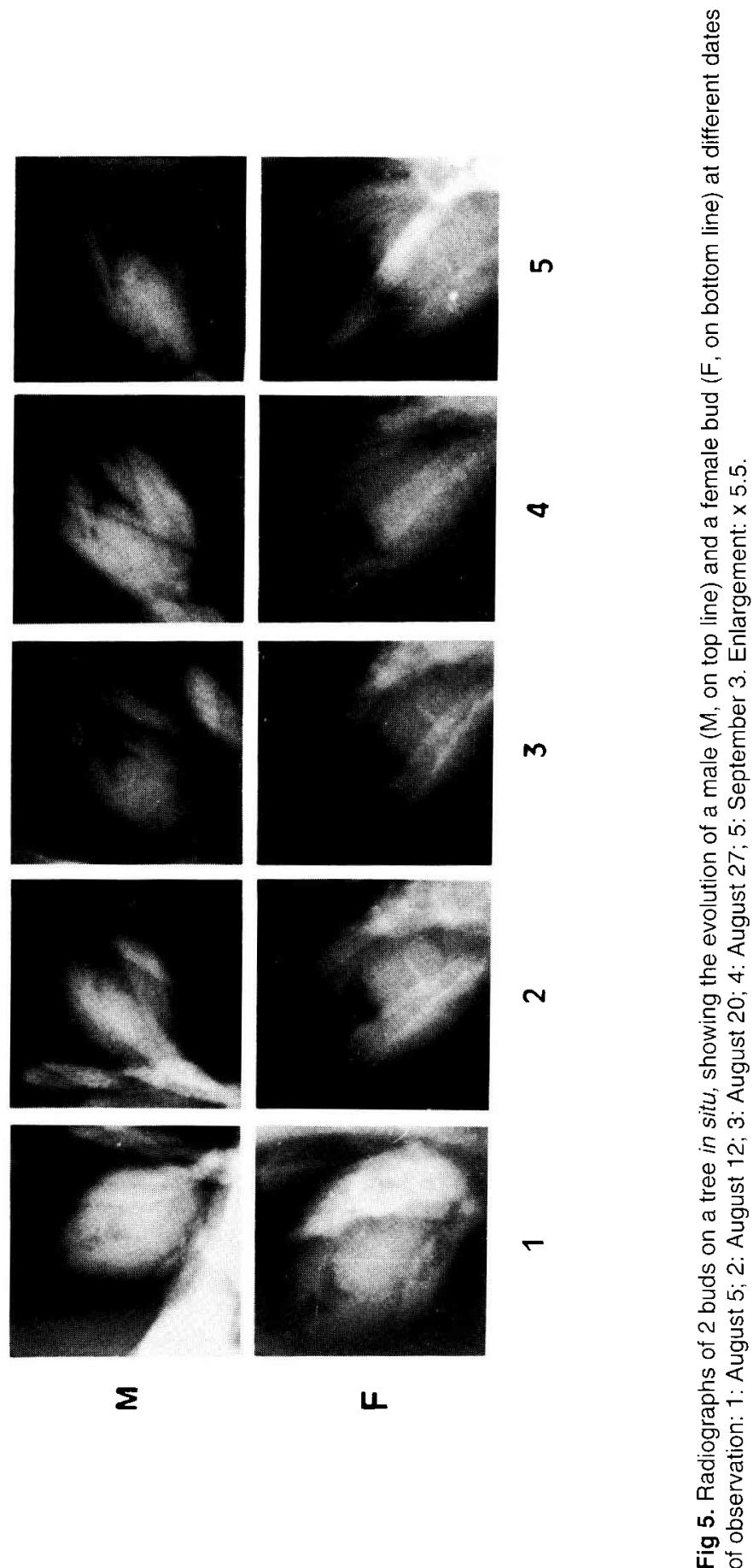

$N$

u

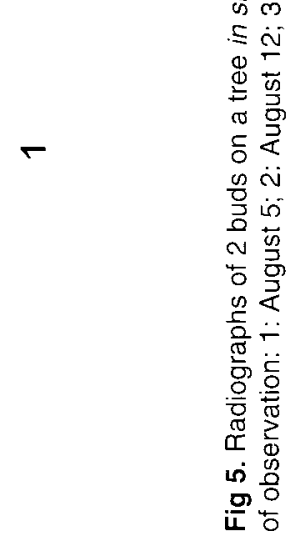



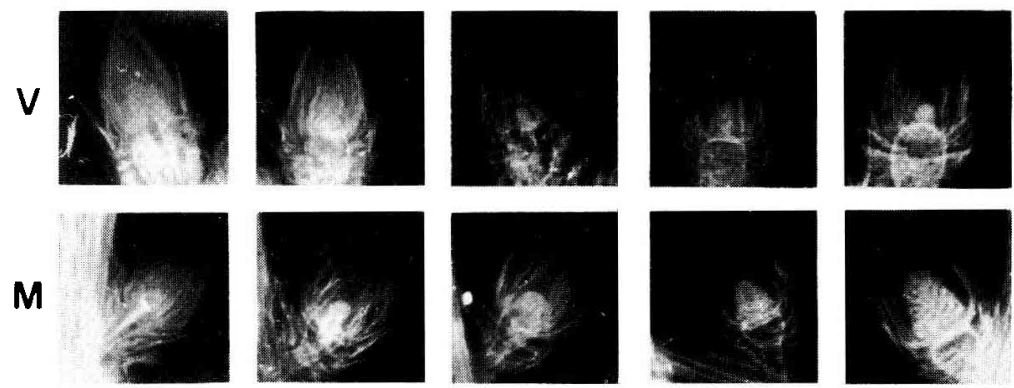

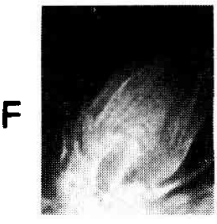

1

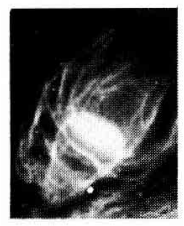

2

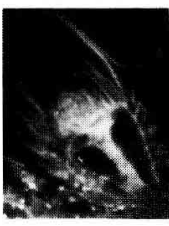

3

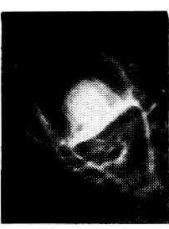

4

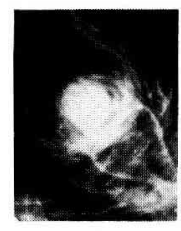

5

Fig 6. Radiographs of buds on cut and treeze-dried shoots, showing evolution of a bud (vegetative (V) on top line, male (M) on middle line and female (F) on bottom line) at different dates of sampling: 1: July 31, 2: August 13, 3: August 22, 4: September 2, 5: October 3. Enlargement : $\times 3.5$

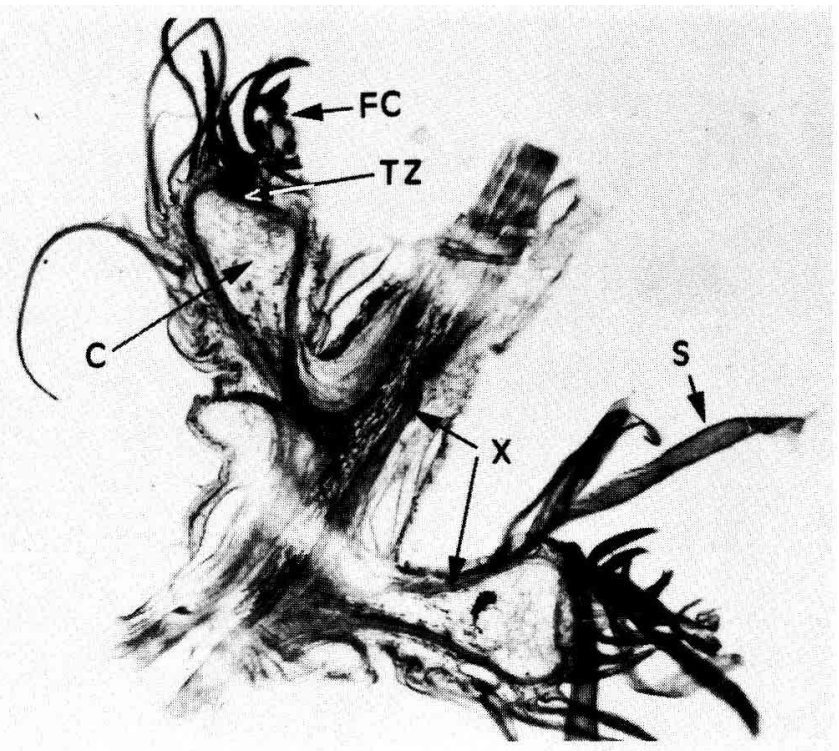

Fig 7. Histologic section showing vascularization and the 'chamber' $(C)$ delimited by $x y l e m(X)$ and transition zone (TZ) at the base of female buds, on September 3. Female cone (FC) was partially destroyed or masked by scales (S) of bud. Enlargement: $x 13$. 
seems highly improbable that chromosomic damage appeared, because of the small doses of radiation accumulated ( 25 rads for 1 h of exposure which represents about 12 pictures) compared to the $\mathrm{LD}_{50}$, about 20000 rads for seeds, or to the doses used to induce mutagenesis in apple or pear buds (2 000 to 5000 rads).

It therefore seemed useful to adapt this technique to a material like conifer buds. Although they present certain disadvantages (they are thicker than seeds and have a higher water content) previous attempts on other species gave promising results (Chavagnat, 1988).

We did encounter drawbacks with the $X$ ray technique. In particular, the inability to obtain pictures precise enough for the observation of the meristematic apex made it impossible to apply the height/width ratio of the apical meristem used by Owens and Smith (1964), Owens (1969), and Allen and Owens (1972) to describe the anatomical development of the meristem.

However, we did observe some early morphologic differences and precise changes in structure. The analysis of floral morphology must be associated with an analysis of the morphology of the buds (shape and angle of scale insertion) to distinguish very early vegetative buds from floral buds and to differentiate between male and female floral buds.

We were unable to achieve pictures as sharp as those obtained with seeds but can foresee interesting applications. The growth and development of floral parts inside buds could be studied non-destructively, thereby allowing precise kinetic studies on small quantities of material. Homogeneous samples of buds could be selected in situ on the basis of their real state (for later biochemical analysis, for example) at a stage when external morphological characteristics would make it impossible.
Improvements in the definition of radiographs can be expected and we are confident that there will be greater future developments of this technique in biology.

\section{ACKNOWLEDGMENTS}

We particularly thank A Chavagnat for introducing us to the radiography technique and for his very useful advice. We also thank $C$ Bodet, $P$ Delanzy, N Frizot and JP Richard for technical assistance.

\section{REFERENCES}

Allen GS, Owens JN (1972) The Life History of Douglas Fir. Ed Environment Canada Forestry Service, $139 p$

Bonnet-Masimbert M (1987) Floral induction in conifers: a review of available techniques. For Ecol Manage $19,135-146$

Bonnet-Masimbert M (1989) Promotion of flowering in conifers: from the simple application of a mixture of gibberellins to more integrated explanations. Ann Sci For 46 (suppl), 27s-33s

Chavagnat A (1984) Détermination de la qualité des semences horticoles par radiographie industrielle aux rayons X. PHM Revue Horticole 249, 57-61

Chavagnat $A$ (1985) La radiographie industrielle aux rayons $X$. Contrôle de la qualité des semences et autres applications en agronomie. CR Acad Agri Fr $71,5,457-463$

Chavagnat A (1988) Nouveau: la radiographie industrielle aux rayons $X$ pour la protection des plantes. Phytoma 401, 13-21

Johansen D (1940) Plant Microtechnique. McGraw Hill Book Company Inc, New York, $59 \mathrm{pp}$

Owens JN (1969) The relative importance of initiation and early development on cone production in Douglas fir. Can J Bot 4, 1039-1049

Owens JN, Smith FH (1964) The initiation and early development of the seed cone of Douglas fir. Can $J$ Bot 42, 1031-1047

Simak M, Gustafsson A (1953) X-photography and sensibility in forest tree species. Hereditas $39,458-468$

Simak M, Sahlen K (1981) Report of the forest tree seed committee working group on X-testing 1977-1980. Comparison between the $X$-radiography and cutting test used in seed quality analysis. Seed Sci Technol $9,1,205-227$ 